\title{
FORGING ON COPPER BETWEEN CRAFT AND CREATIVITY
}

Salah Shaaban Hassanein ABDEL RAHMAN *

Department of Sculpture, Faculty of Fine Arts in Luxor - South Valley University, Egypt

\begin{abstract}
Minerals are one of the most abundant elements in nature, and they have a strong and distinctive presence and influence in human civilization, as they have contributed, with their multiple capabilities, to achieving many achievements, starting from simple metal tools to powerful compounds. The discovery of minerals is a revolution in the history of the development of human thought, as it moved from the era of stone use to the era of metal use and the subsequent discovery of its strength and uniqueness, and one of the most important minerals that had a great impact on industrial development is copper metal, which was used in the past in the manufacture of weapons and tools.

Keywords

Forging, Copper, Craft, Creativity.
\end{abstract}

\section{Introduction:}

utensils and was also used in the field of arts, where the ancient Egyptian artist used it in casting artworks and transforming them into bronze, and the use of copper ore in the artistic field has passed through many stages of development, as the Coptic artist and the Islamic artist used it in the manufacture of copper pots and lamps, which were not It is used for the utilitarian purpose only, but the artist beautified it with a lot of artistic inscriptions from the motifs and subjects that abound in each of these arts, and Coptic art and Islamic art have left us with a great heritage of these copper artworks, which is rich in many artistic and aesthetic values, and this material has not been used. Noble at the end of those ages, but the children inherited it and became one of the famous crafts that the modern Egyptian artist cared about, as shaping copper by scratching or hammering became a form of The types of modern artistic creativity, and the Egyptian artist, especially in the Khan al-Khalili area, excelled in copper works, where the children excelled in drawing inspiration from their great artistic heritage in that material, and this creativity was not limited to the craftsman only, but extended to the art academies, where he started using that material in Technical colleges, and the academic artist specialized in technical colleges has developed the use of raw materials, instead of forming by scratching, he used methods on various copper foils, to present to us wonderful artistic works that testify to the ability of the contemporary Egyptian artist to present new artistic thought, and to draw inspiration from his artistic and cultural heritage, and keep pace with Global artistic development, including its artistic and creative doctrines, the research provides a study of development, the craft of shaping on copper and its role in preserving the cultural heritage and

* Corresponding author: finearts@ fart.luxor.edu.eg 
how to draw inspiration from the Egyptian heritage vocabulary in creating new artistic works that carry the Egyptian spirit and preserve the originality and national identity

\section{$\underline{\text { Research problem: }}$}

1- Raw materials are widely available in nature, including minerals and other ores, but the hand that extends to extract these treasures and present them to serve humanity has to be done.

2- The use of copper ore in technical processes has gone through many stages and many developments since ancient times. Therefore, it is necessary to shed light on these stages and study them to find out how to develop and benefit from them in a manner suitable for the modern era.

\section{Copper ore components and types:}

The material is the material present in nature, which man must intervene as a mediator to reveal it, and the raw material does not acquire an artistic formula and becomes an aesthetic material until after the artist's hand has extended to it and made it an aesthetic sensation. "So the material is the medium of formation between what is going on in the soul. From creative imaginations and between what is embodied in tangible material works, copper ore is considered throughout the ages as one of the minerals that attract artists and has an aesthetic appearance that stirs their artistic imaginations, and it is one of the most important metals and the most common and used in our time. Copper and among the copper ores that were used in its extraction on a small scale is sulfur, tenorite, bronite, chalcocite, coflite and copper sulfide, and it has been recognized since ancient times, and has been used in many diverse works in the field of metal forming, and copper has many properties, including plasticity, hardness, flexibility, ductility and methods And mechanical resistance and good conductivity of electricity.Copper is found in many forms, the most important and most common of which are red copper and brass.

Copper Red: The red copper metal is considered one of the noble metals that is highly resistant to rust, and it is one of the most produced metals due to the wide range of use. To break, it has a surface appearance, attractive and shiny after polishing, and it can also be tinted with heat and oxidation.

- Brass: (brasses): it is an alloy of red copper and zinc, and it is characterized by ease of casting, operation and high resistance to corrosion in water and air, and it is suitable for forming and welding with silver and tin, and it is cheaper than red copper and more used in industries because it is easy to form by pressing, and hammering, Lathing, and it can be turned on cold and is subjected to cracking if it is placed on the protector and to color it, it is fermented by heating it to a dark red color, then it cools slowly, and a lot of fermentation is necessary because copper dries quickly due to the impact of operating processes, and in the present time many 
types of popular jewelry are made of it, as it is used. Expanding in the manufacture of pipe fittings, electrical wires, marine engineering, and many industrial uses.

- Methods of forming copper: The copper ore has many properties and advantages, and this contributed to the multiplicity of methods of forming this material, and the methods were one of the most important of these methods, which is done either on cold or hot, as well as pressing used in copper forming presses and among the common methods Also, cutting, discharging, welding and assembling parts, but before starting to form copper, it must be prepared for shaping.

Preparing copper for hammering: Methods are the property that allows a permanent change in the shape of the metal without being broken, and this is done either by heating the metal or hammering it on cold, and methods are the oldest methods used in forming metals, as man has known them from time immemorial, and it is more Our stomach is one of the automatic forming methods, but the use of methods enables more creative shapes to be produced than can be produced by forming machines. And the methods are usually understood as a method of forming without cutting, moreover, the work that is formed by forging is often characterized by higher durability than the work that is formed by cutting methods, and the methods of the commonly used methods are forging with flat-die hammers, forming with hammers by hammer and anvil, and forming metals. By manual methods of converting them into solid figures of specific shapes and dimensions, so that they become parts or pieces according to specific designs that achieve the purposes for which they are made. Metal pens are hammered with steel pens of various sizes and shapes and have geometric ends. Some of them are square, circular, or half Circular, triangular, rectangular, and spherical, and these pens are knocked by a special iron hammer with two faces, one of which is tapered and the other has a wide circular flat. There are two methods of forming copper in the method of hammering.

The first method: vaulting formation: which is called ribosia, and it is intended for prominent and deep formation on the surface of copper, and this method is considered one of the known methods of forming metals since ancient times, and it uses steel pens or rods of various sizes and shapes with geometric edges such as straight and sharp. And the half is sharp, or with square, triangular, circular, or rectangular surfaces, sharpened or semi-curved, and it is called ribosome pens, and the function of these films is limited to pushing, refining and smoothing shapes, and this diversity of shapes is due to the artist who himself shapes them according to his design, so each pen has its own function Special subordinate form of syllable.

The second method: the methods are using moving cushions without fixing the copper piece, but through the process of fermentation and continuous cleaning, and the methods using 
wooden and rubber cushions or bags of dry sand or using metal brackets. It is used in the implementation of works with large details, open spaces, linear lines, and similar to geometric shapes, and this method is also used during the implementation of methods using the first method, between each stage of the removal and fixing of the plate, that is, in the period between removing the plate from the surface of the bitumen, after its fermentation and before Putting it again to complete the methods, this requires some methods on non-stick cushions in order to make some adjustments, including leveling the surface of the board and the floor, especially in the case of works that are characterized by geometric shapes and straight sculpture heights, and cold hammering is done using hammers, chisels, anvils, sickles and bends. The method of producing works of an applied nature, especially in the production of copper pots and the decoration on them by filling the container with a quantity of hot tar and leaving until it cools and striking it from the outside.

Craft and Creativity: Definition of the craft: the handicraft or traditional industries, which are industries that depend on the hand or using simple tools only, and this term is usually called the traditional means of manufacturing Kurdish goods. One of the most important criteria for crafts is that these items or products are of cultural, religious or life significance and provide a material income.

Definition of craftsman: is a skilled manual worker in a certain trade or craft, and from an economic and social point of view, the condition of the craftsman is in a middle position between the worker and the professional. - Definition of creativity: it can be defined as every new, useful, original and socially acceptable production, which is the organization of ideas and their emergence in a new structure based on existing elements, and creativity is a human mental state that tends to create ideas or methods and means that are very novel and unique, so that they constitute a real addition to the total human product. It will also be of real benefit on the ground, and creativity has four components:
A- Creative work
B- The creative process
C- The creative person
D- Creative attitude

\section{The artistic use of copper ore through the ages in the history of Egyptian art:}

The use of copper ore in depositing artworks has gone through many stages starting from ancient Egyptian art and extending to modern Egyptian art, and it has played a major role in highlighting the position of the prominent art of sculpture through the ages, through the decoration of pots with wonderful formations of relief and bas-relief, which continued from 
During this period, some of the features of the prominent ancient Egyptian sculpture, whose impact appeared in Coptic and Islamic art, as well as in modern art, as evidence of artistic and creative communication between the generations of the Egyptian artist in his different ages. The copper ore had an important role in the life and artistic uses of the ancient Egyptians. The Egyptian manufacturer used hammers to turn pieces of metal into hammered sheets and he could form them however he wanted. The gold metal was more used in artworks in ancient Egypt. "Gold was used in Egypt since the ancient era, and it was used until the Twenty-second Dynasty in making jewelry and making covers for fingers and toes, while copper was used more in the manufacture of utensils and it was an industry Jugs and bowls are made of hammered copper in the first family, and were intended only for the use of the pharaoh, then the nobles began to use them in the third dynasty, while the common people used pottery vessels, and the ancient Egyptian artist left us a lot of hammered copper works, which the artist inspired from. The Coptic artist added a lot of his artistic deposit to it. The Coptic artist found his desired artistic goal in using metals in his artistic works, and he used them to represent the shapes of birds and animals. "The Coptic artist also used metals in making tools associated with the church, such as incense burners, crosses, saddles, and candlesticks, which were made by hammering on copper. It was cast with bronze, which is a mixture of copper and some other metals. These utilitarian uses of copper work continued in the Islamic era. Which gave it a lot of aesthetic values, and developed many methods and methods for its decoration and embellishment with bas-relief and bas-relief . The Muslim artist excelled in making copper products from jugs, stoneware, incense burners, chandeliers, utensils and statues (his shape), which he covered their surfaces with plant and animal motifs and writings used in that prominent and bas-relief sculpture Covered with precious metals of gold and silver, which is known as "takfit", the Muslim artist left us a huge wealth of copper works, which testify to his progress and ingenuity in forming copper ore, which continued to be used and shaped until modern times and whose teachings were derived from previous arts.

\section{Khan Al-Khalili School of Copper Formation:}

Craftsmen have been accustomed since ancient times to settle in their own neighborhoods in which their workshops are in which they work as well as their homes, due to the difficulty in providing means of transportation at that time, and the craft of making copperwork, along with the craftsmen working in this craft, was concentrated in "Khan Al-Khalili, especially in the famous Al-Jamalia neighborhood" Now located in Old Cairo, which was named after the Emir of the armies in the Fatimid era, the minister "Badr al-Din al-Jamal," who reorganized Cairo and established many neighborhoods, including the neighborhood of "Al-Nahhasin", and that 
area was distinguished as an important industrial area, as it contained many workshops And the markets and commercial agencies, and the concentration of the copper crafts industry and the state's concern for them had a great role in the prosperity and prosperity of that industry, which has continued to this day in that famous neighborhood, which is characterized by this industry along with other important industries, and Khan al-Khalili was rightly the school that preserved The artistic heritage, methods and methods used by the predecessors and passed down to later generations in that industry. One of the most important crafts that can be passed down to generations, and the craftsmen in Khan al-Khalili used to imitate pieces of metal artifacts from the Mamluk, Ayyubid and Fatimid eras, especially those adorned with plant and animal motifs and calligraphy, and the craftsmen in Khan al-Khalili were not interested in presenting new designs of their own, but contented themselves with imitation and transfer of the arts The previous one, as for dealing with the surrounding reality with all its political, social and life vocabulary, in designs executed by means of methods on copper, did not appear until after the emergence of modern Egyptian sculpture. The public used to push their children to the owners of copper workshops to learn this important craft, because it is so popular that it guarantees them a good future of life, and Al-Nahasin Street in Khan Al-Khalili ended up with the shops that sell manufactured products and raw materials, and the workshops have moved to the Hawari And the neighboring neighborhoods, "The children inherited the craft from their parents generation after generation, and they lived in the region throughout these generations, while others came from outside the region, but the craft, with its traditions and the region with its urban, economic and demographic characteristics, made them a single and interconnected group involved in one distinct work. These craftsmen were able to preserve the craft of shaping copper, and the craft was also able to make them a homogeneous society whose members share in preserving these important traditional crafts and industries, and they were able to teach that craft to many succeeding generations who are still working in this craft until our present time. Machining by methods on copper and its role in enriching contemporary plastic art: The School of Fine Arts, which was established in Cairo in 1902 CE, was the true beginning of modern Egyptian art. Its role appeared through the students of its first classes who carried the banner of modern Egyptian art, Mahmoud Mukhtar was the first pioneer of the modern Egyptian art of sculpture, and his influence with ancient Egyptian art appeared in form and content

\section{Findings and Recommendations:}

1- Shaping by methods on copper is one of the most important and prominent sculpture arts in Egypt, in the past and present. Therefore, attention must be paid to this art from the state and scientific academies. 
2- The formation of copper and minerals has gone through many stages of development through different ages. Therefore, these stages must be studied, preserved, and developed to suit the modern era.

3- Craftsmen and craftsmen have had a great role in preserving many heritage industries, including the formation of copper and metals. Therefore, attention must be paid to small crafts and help craftsmen continue and develop.

4- The contemporary Egyptian artist has succeeded in blending the heritage and contemporary spirit in producing art. Therefore, attention must be paid to studying the history of arts and crafts and small industries to contribute to their development and preservation.

References:

1- Ahmed Fouad Selim: An eyewitness to the contemporary Egyptian art movement. The Egyptian General Authority for Book 2009.

2- Alfred Lucas - translated by Zaki Iskandar: Materials and industries among the ancient Egyptians at the Egyptian Book House, Cairo.

3- Jerome Solins: Translated by Fouad Zakaria: Art Criticism - Aesthetic and Philosophical Study, The General Egyptian Book Authority and Cairo 1971.

4- Jamil Abdul Majeed Fouad, Metals, Dar Al Fikr Al Arabi, 1971 - Samir Shushan: Technology of Metal Formation and Dar Al Hadary for Printing and Publishing, Alexandria, 2009.

5- Saleh Reda: The New Expressionist Narrative in the Works of the Artist Qasim Hussein, The National Center for Fine Arts Exhibition Catalog 18.

6- Margaret Mery, translation of Muharram Kamal: Egypt and its Eternal Glory, Series of A Book of the Arab Statement Committee

7- Mona Kamel Al-Essawi, from the folklore of metalwork, appointed for studies and humanitarian research, 2009.

8- Mahmoud Bakshish: "Article" by Muhammad Rizk between Al-Hadid and Al-Nahas and Al-Hilal Magazine, Issue, March 2000, Dar Al-Hilal Publishing.

9- Nemat Ismail Allam: Arts of the Middle East from the Greek Conquest until the Islamic Conquest, House of Knowledge.

10- Kamal Al-Malakh: Jamal Al-Sigini, "Description of Modern Egypt Series, State Information Service, Cairo.

11- Enas Badr Al-Din SAQR, ARTISTIC STRAINS AND THE CONTINUITY OF

CREATIVE VISION, International Journal of Multidisciplinary Studies in Art and

Technology, Vol. 1, No. 2, 2018, pp. 1-4. 
12- Sanajak Ibrahim Mustafa MUHAMMAD and Naglaa Ezzat Ahmed MAHMOUD, CREATING MODERN DESIGNS FOR NARROW INTERIOR SPACES INSPIRED BY THE ART OF ORIGAMI, International Journal of Multidisciplinary Studies in Art and Technology, Vol. 1, No. 2, 2018, pp. 5-9.

Received: February 25, 2019

Accepted: April 22, 2019 